\title{
Comment on 'The burden of occupationally-related cutaneous malignant melanoma in Britain due to solar radiation'
}

\author{
William B Grant ${ }^{\star, 1}$
}

${ }^{1}$ Sunlight, Nutrition, and Health Research Center, PO Box 641603, San Francisco, CA 94164-1603, USA

Sir,

A recent paper in the British Journal of Cancer estimated that the attributable fraction for cutaneous malignant melanoma (CMM) from solar exposure due to outdoor occupation was 241 cases in 2011 and 48 deaths in 2012 (Rushton and Hutchings, 2017). They used odds ratios for CMM mortality rates for outdoor occupations from a study conducted in the United States in low sun regions (Freedman et al, 1997). This finding is at odds with a meta-analysis that found non-significant pooled odds of CMM for high vs low occupational sun-exposure category in eight highlatitude countries: odds ratios $=1.0$ for trunk, 0.8 for limbs, and 1.2 for head and neck (Chang et al, 2009).

It is also at odds with a study based on cancer incidence rates by occupation in five Nordic countries (Grant, 2012). That study was an analysis of 2.8 million cancer cases for the period 1961-2005 for 54 occupational categories (Pukkala et al, 2009). The index of personal UVB exposure developed for this data set was the standardised incidence of lip cancer, which was less than the standardised incidence of lung cancer. That this index was appropriate was supported by the finding that it was inversely correlated with 14 types of internal cancers, in good agreement with an ecological study from the United States (Grant and Garland, 2006) and several other ecological studies from single mid-latitude countries (Moukayed and Grant, 2013). The UVB exposure index was significantly inversely correlated with CMM incidence for men. The result for women was indeterminate due to the fact that women have little risk of lip cancer due to wearing lipstick. On the basis of this study, it is very likely that outdoor workers in Britain would have lower risk of many types of cancer including CMM than indoor workers. In addition, those who spend more time in the sun enjoy better health in general and lower mortality rates (Wright and Weller, 2015; Lindqvist et al, 2016).

\section{CONFLICT OF INTEREST}

Funding was received from Bio-Tech Pharmacal Inc. (Fayetteville, AR, USA), and recently received from the Vitamin D Society (Woodstock,
Ontario, Canada) and the Vitamin D Council (San Luis Obispo, CA, USA).

\section{REFERENCES}

Chang YM, Barrett JH, Bishop DT, Armstrong BK, Bataille V, Bergman W, Berwick M, Bracci PM, Elwood JM, Ernstoff MS, Gallagher RP, Green AC, Gruis NA, Holly EA, Ingvar C, Kanetsky PA, Karagas MR, Lee TK, Le Marchand L, Mackie RM, Olsson H, Østerlind A, Rebbeck TR, Sasieni P, Siskind V, Swerdlow AJ, Titus-Ernstoff L, Zens MS, Newton-Bishop JA (2009) Sun exposure and melanoma risk at different latitudes: a pooled analysis of 5700 cases and 7216 controls. Int J Epidemiol 38(3): 814-830.

Freedman DM, Zahm SH, Dosemeci M (1997) Residential and occupational exposure to sunlight and mortality from non-Hodgkin's lymphoma: composite (threefold) case-control study. BMJ 314(7092): 1451-1455.

Grant WB, Garland CF (2006) The association of solar ultraviolet B (UVB) with reducing risk of cancer: multifactorial ecologic analysis of geographic variation in age-adjusted cancer mortality rates. Anticancer Res 26(4A): 2687-2699.

Grant WB (2012) Role of solar UV irradiance and smoking in cancer as inferred from cancer incidence rates by occupation in Nordic countries. Dermatoendocrinol 4(2): 203-211.

Lindqvist PG, Epstein E, Nielsen K, Landin-Olsson M, Ingvar C, Olsson H (2016) Avoidance of sun exposure as a risk factor for major causes of death: a competing risk analysis of the melanoma in Southern Sweden cohort. J Intern Med 280(4): 375-387.

Moukayed M, Grant WB (2013) Molecular link between vitamin D and cancer prevention. Nutrients 5(10): 3993-4023.

Pukkala E, Martinsen JI, Lynge E, Gunnarsdottir HK, Sparén P, Tryggvadottir L, Weiderpass E, Kjaerheim K (2009) Occupation and cancer - follow-up of 15 million people in five Nordic countries. Acta Oncol 48(5): 646-790.

Rushton L, Hutchings SJ (2017) The burden of occupationally-related cutaneous malignant melanoma in Britain due to solar radiation. Br J Cancer 116(4): 536-539.

Wright F, Weller RB (2015) Risks and benefits of UV radiation in older people: More of a friend than a foe? Maturitas 81(4): 425-431.

This work is published under the BJC's standard license to publish agreement. After 12 months the license terms will change to a Creative Commons AttributionNonCommercial-Share Alike 4.0 Unported License. 